\title{
The Reef Coral Coscinaraea marshae Is Not a High-Latitude Endemic
}

\author{
Bert W. Hoeksema ${ }^{1,2,3, * \mathbb{D}}$, Ofri Johan ${ }^{4} \mathbb{D}$ and Andreas Kunzmann ${ }^{5}(\mathbb{D}$ \\ 1 Taxonomy, Systematics and Geodiversity Group, Naturalis Biodiversity Center, P.O. Box 9517, \\ 2300 RA Leiden, The Netherlands \\ 2 Groningen Institute for Evolutionary Life Sciences, University of Groningen, P.O. Box 11103, \\ 9700 CC Groningen, The Netherlands \\ 3 Institute of Biology Leiden, Leiden University, P.O. Box 9505, 2300 RA Leiden, The Netherlands \\ 4 Research Institute for Ornamental Fish Culture, Jl. Perikanan No. 13, Pancoran Mas, \\ Kota Depok 16436, Jawa Barat, Indonesia; ofrijohan@kkp.go.id \\ 5 Department of Ecology, Leibniz Centre for Tropical Marine Research (ZMT), Fahrenheitstr. 6, \\ 28359 Bremen, Germany; andreas.kunzmann@leibniz-zmt.de \\ * Correspondence: bert.hoeksema@naturalis.nl
}

Citation: Hoeksema, B.W.; Johan, O.; Kunzmann, A. The Reef Coral Coscinaraea marshae Is Not a High-Latitude Endemic. Diversity 2021, 13, 681. https://doi.org/ $10.3390 / \mathrm{d} 13120681$

Academic Editor: Michael Wink

Received: 29 November 2021 Accepted: 15 December 2021 Published: 19 December 2021

Publisher's Note: MDPI stays neutral with regard to jurisdictional claims in published maps and institutional affiliations.

Copyright: (c) 2021 by the authors. Licensee MDPI, Basel, Switzerland. This article is an open access article distributed under the terms and conditions of the Creative Commons Attribution (CC BY) license (https:// creativecommons.org/licenses/by/ $4.0 /)$.

\begin{abstract}
The 'temperate' reef coral Coscinaraea marshae Wells, 1962, is reported from Siberut Island (West Sumatra, Indonesia), a near-equatorial locality, $3375 \mathrm{~km}$ away from its northernmost range limit in Western Australia, where it is considered a high-latitude endemic. This tropical record suggests that the latitudinal distributions of poorly recorded reef corals may not yet be fully understood, which might be relevant in the light of progressing seawater warming.
\end{abstract}

Keywords: endemism; near-equatorial locality; subtropical; temperate water; tropicalization

\section{Introduction}

As a result of on-going marine biodiversity surveys, species continue to be discovered as new to science or as representatives of new locality records, especially on coral reefs in marine biodiversity hotspots, such as the Central Indo-Pacific. Such discoveries become increasingly intriguing when taxa are spotted in unexpected localities far outside their known range, such as the zooxanthellate scleractinian coral Echinomorpha nishihirai (Veron, 1990) which has been located in the Great Barrier Reef, instead of its type locality in southern Japan [1]; and the azooxanthellate scleractinian Astrangia woodsi Wells, 1955, first assumed to be a southern Australian endemic, but recently recorded from the Indian coastline of the eastern Arabian Sea [2]. Another example of a species that has been found at an unexpected locality is the azooxanthellate, cave-dwelling coral Leptoseris troglodyta Hoeksema, 2012, which was previously only known from depths $<30 \mathrm{~m}$ in the West Pacific Ocean, but was recently discovered in the SW Indian Ocean between 65 and $90 \mathrm{~m} \mathrm{[3].}$ Such new remote records are typically serendipitous and usually concern poorly recorded species, which suggests that their ranges are disjunct, with limits that are poorly known [1].

Because of their biogeographic isolation, only a few tropical marine regions are known to harbour reef coral species that are reputed endemics. The subtropical-temperate waters in southern Australia, also referred to as extra-tropical Australia [4,5], are known to house 30 endemic scleractinian corals, 12 of which can be found at $<30 \mathrm{~m}$ depth [6]. Astrangia woodsi does not belong among these species anymore [2], but Australopsammia aurea (Quoy and Gaimard, 1833) is considered a new member of this category [7].

Three southern Australian endemics are recognized as zooxanthellate reef corals: Coscinaraea marshae Wells, 1962, C. moneilli Wells, 1962, and Australophyllia wilsoni (Veron, 1985) $[5,6,8,9]$. Coscinaraea marshae has $28.5^{\circ} \mathrm{S}$ as northernmost distribution record off Western Australia [10] and is called a temperate-water specialist [11] and a high-latitude endemic [5]. It has received much attention with regard to its susceptibility to bleaching 
during a period of elevated seawater temperatures in $2010-2011$, at $26.5{ }^{\circ} \mathrm{C}$ instead of the regular $22{ }^{\circ} \mathrm{C}$ in summer [12-14]. Usually, reef coral growth requires a minimum temperature of $18{ }^{\circ} \mathrm{C}$ [5], whereas the seawater surface has a range of $25-28{ }^{\circ} \mathrm{C}$ in the tropics and $19-28^{\circ} \mathrm{C}$ in the subtropics [15].

This report presents information on where and how Coscinaraea marshae (Figures 1 and 2) was found in Siberut Island (Indonesia), which is close to the equator at $01^{\circ} 28^{\prime} 48^{\prime \prime} \mathrm{S}$, and $3375 \mathrm{~km}$ away from its northernmost locality record in the Wallibi Group of the Houtman Abrolhos islands, Western Australia (Figure 3a). Siberut Island is situated off Padang, the capital of West Sumatra province. The reefs in the proximity of Padang consist of (1) inshore fringing reefs along the mainland shore-line, (2) patch reefs on a near-shore narrow shelf (max. $200 \mathrm{~m}$ deep; Figure 3b), and (3) fringing reefs around the offshore Mentawai Islands, including Siberut $[16,17]$. The Mentawai Islands are separated from Sumatra by the 1900-m deep Mentawai Basin (Figure 3b). The conservation needs of this reef area became apparent with the publication of various reports on anthropogenic threats and a massive coral die-off in the 1990s [16-19].
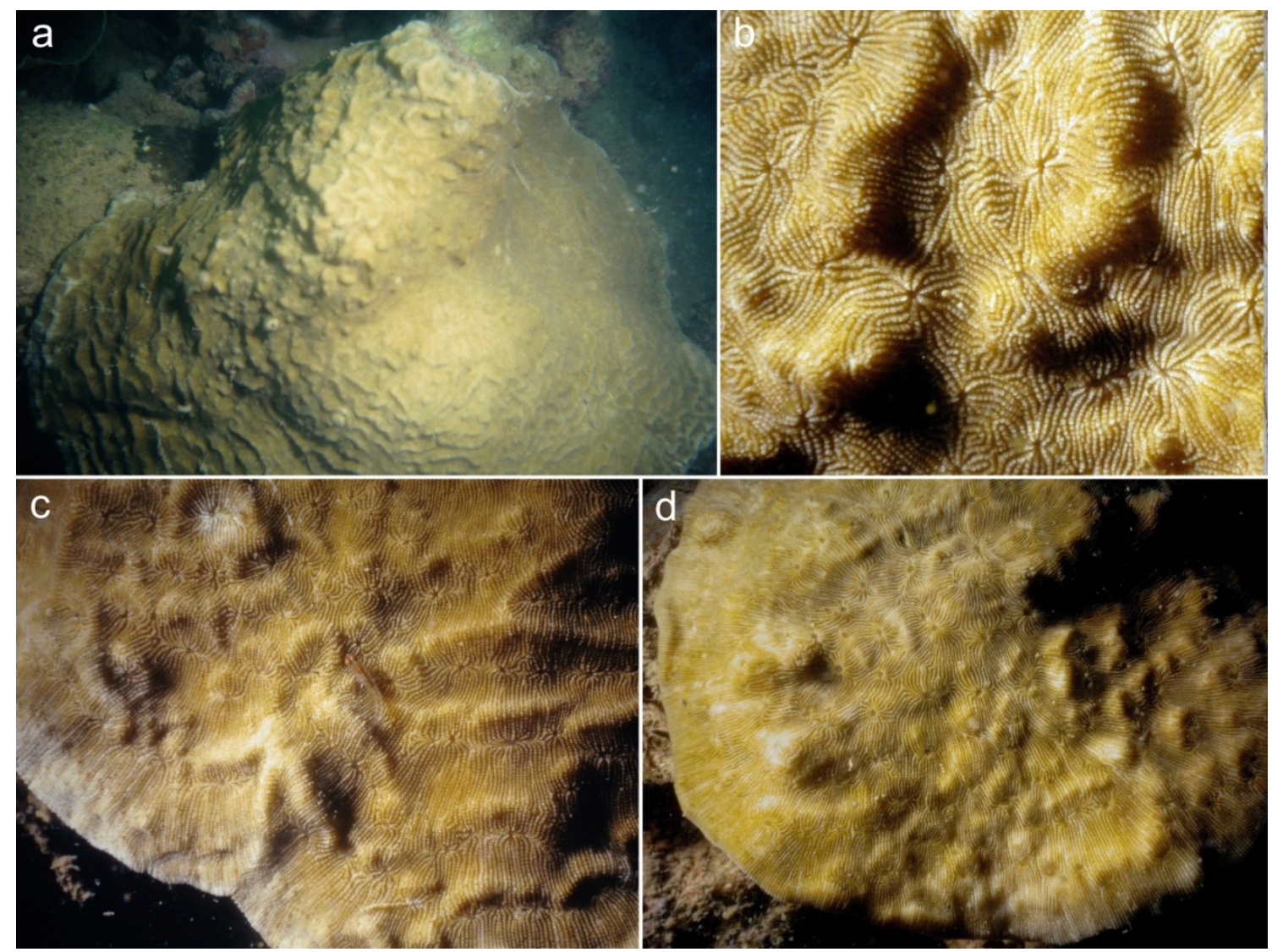

Figure 1. Coscinaraea marshae in Sarabua Bay, Siberut Island, West Sumatra. (a) Large specimen, ca. $50 \mathrm{~cm}$ across. (b) Same specimen; close-up. (c) Smaller specimen, close-up. (d) Smallest specimen. 


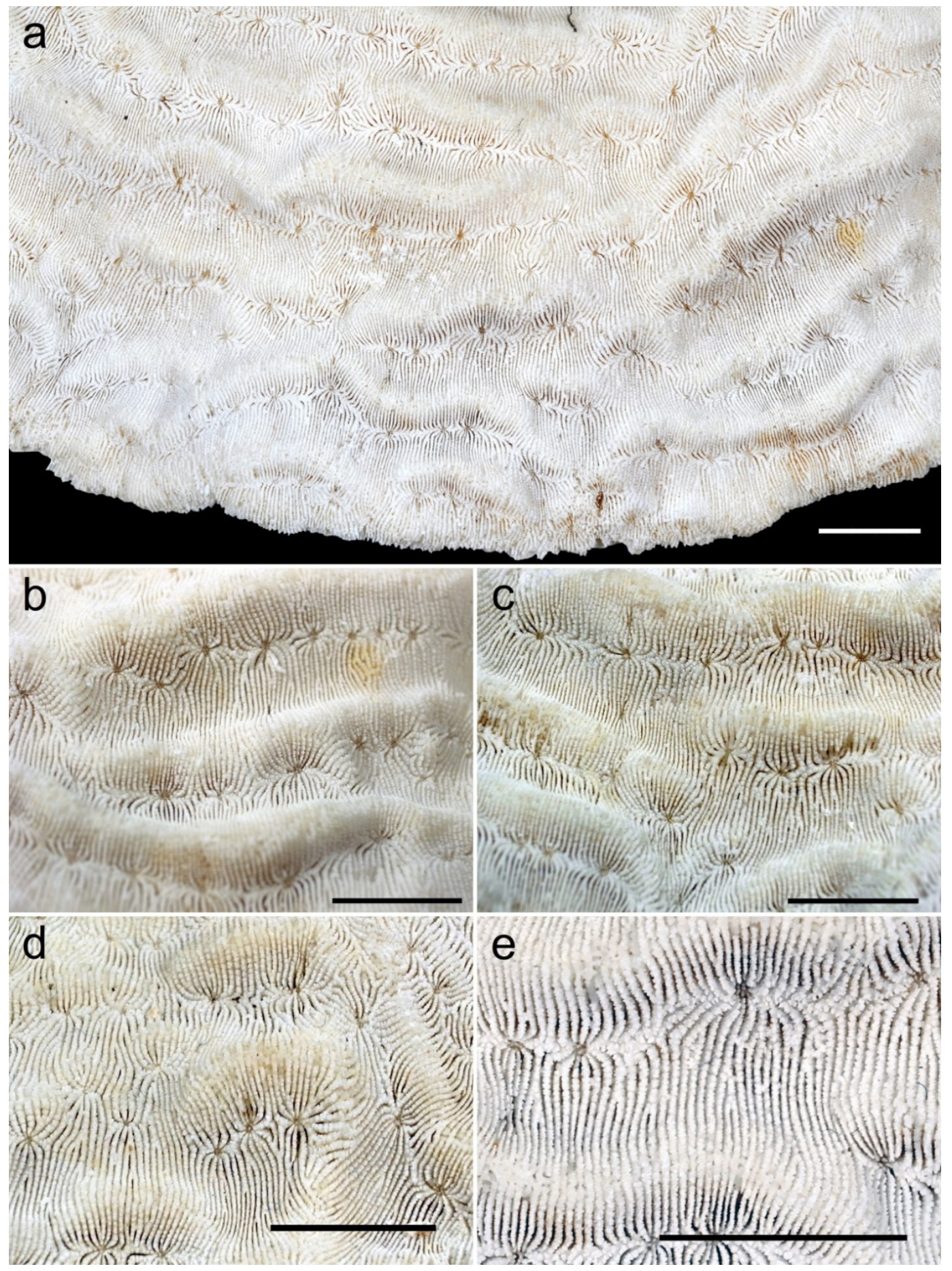

Figure 2. Coscinaraea marshae. Details of coral skeleton fragments (a-e) of a specimen illustrated alive (Figure 1a,b) in Sarabua Bay, Siberut Island, West Sumatra, Indonesia. Scale bars: $1 \mathrm{~cm}$. 

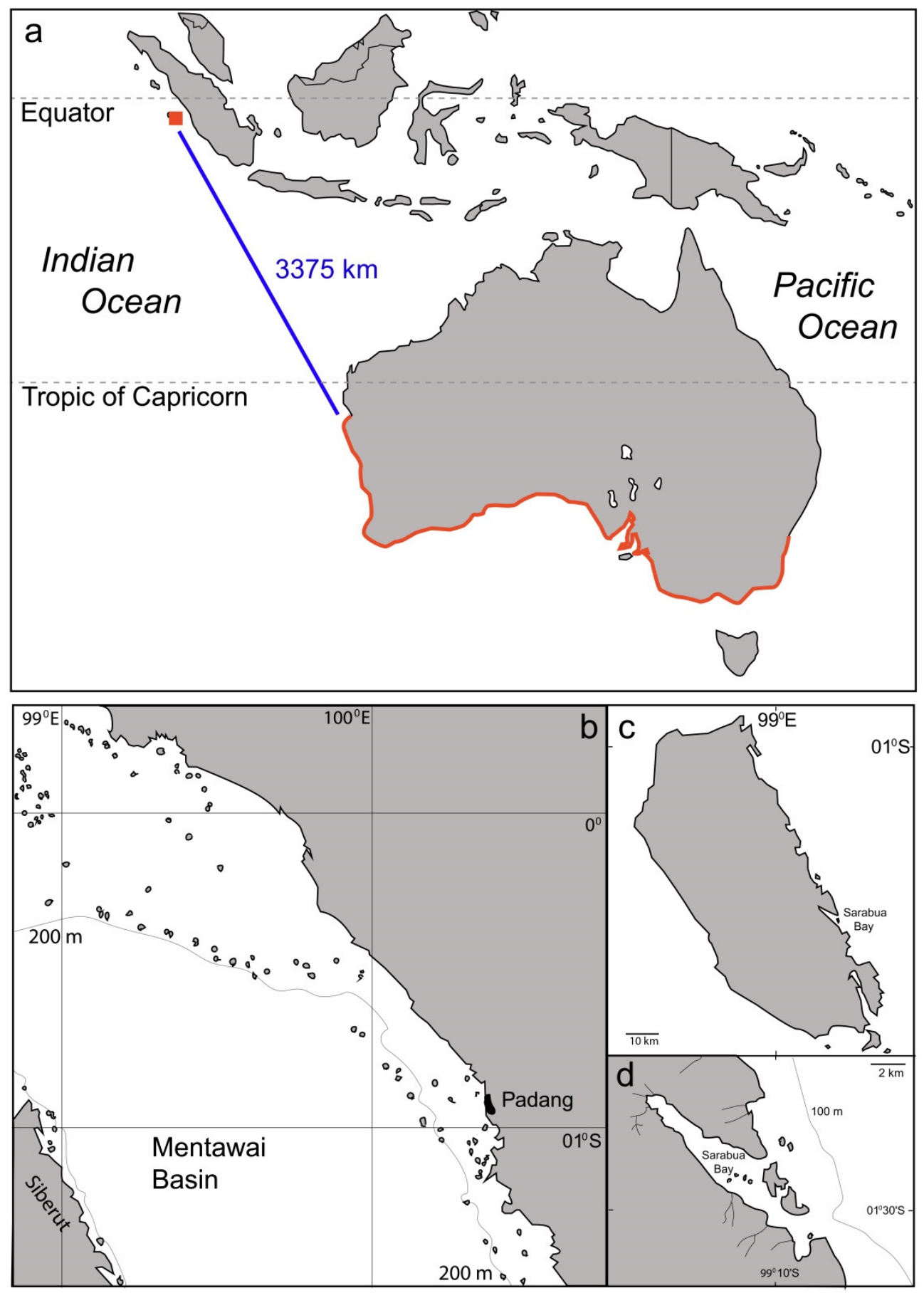

Figure 3. Maps. (a) The distribution (red colour) of Coscinaraea marshae in southern Australia [9] and West Sumatra. (b) The coastal area of Padang city. (c) Siberut Island. (d) Sarabua Bay.

In December 1996, a reef survey was organized to the south-eastern part of Siberut (Figure 3c), whose coastline contains two narrow inland bays. One of these bays, Sarabua Bay, was accessed by the research vessel KM Faperi. This bay runs $7 \mathrm{~km}$ inland (Figure 3d) and has fringing reefs alongshore and around small islets down to a depth of $15 \mathrm{~m}$, where the seafloor predominantly consists of sand and silt. The reefs are very sheltered and could easily be studied with the help of SCUBA. Their dominant tropical coral fauna consisted of massive colonies of, for example, Favites, Dipsastraea, Porites, and Stylocoeniella guentheri (Bassett-Smith, 1890), and foliaceous colonies of, for example, Astreopora, Leptoseris, Pachyseris, and Coscinaraea marshae (Figure 1). Coscinaraea marshae was represented by at 
least four specimens found at a single locality $\left(01^{\circ} 28^{\prime} 48^{\prime \prime} \mathrm{S}, 99^{\circ} 09^{\prime} 42^{\prime \prime} \mathrm{E}\right)$, which is surprising because of its assumed endemism in southern Australia. The sea surface temperature in the bay was not particularly low $\left(28^{\circ} \mathrm{C}\right.$ on 15 January 1996; data from Pusat Studi Pengembangan Perikanan, Universitas Bung Hatta).

Coscinaraea marshae is unique in its genus by having calices arranged in long valleys in between long ridges parallel to the colony margin $[8,9]$, which is demonstrated by overview photographs (Figure 1a,c,d), as well as close-ups of a living coral (Figure 1b) and skeleton fragments (Figure 2) that are deposited in the coral collection of Naturalis Biodiversity Center with catalogue number RMNH.Coel.43418. Calices of congenerics are predominantly separated by corallite walls, as seen in C. monile (Forskål, 1775) [9]. This calls for more thorough taxonomic research of the genus, and of the importance of this character [7], preferably with the use of molecular analyses. Considering the strong morphological resemblance between $C$. monile and C. marshae, both species may appear to be synonymous, but this would not change the finding that $C$. marshae is not a high-latitude endemic. The present record gives cause to new debate concerning the range of this species, in particular with regard to climate and endemism, which may also be relevant for other high-latitude species in light of the expected tropicalization of high-latitude reefs $[14,20,21]$.

There appears to be some confusion on what are considered 'temperate' waters in southern Australia, since Wells [8] argues that the type locality of C. marshae (Rottnest Island at $32^{\circ} \mathrm{S}$ ) falls within the tropical range. Furthermore, more surveys may be needed outside the known range of other high-latitude endemics in order to establish whether they really are non-tropical [2]. The term 'endemism' should be used with caution, especially regarding marine taxa that disperse through larval transport, such as corals. Distribution maps should therefore preferably present real locality records and not extrapolated ranges (as in Figure 3a), which disguise information that could be missing, such as disjunct distributions. The present case, and the one of Astrangia woodsi [2], show that we may understand range limits of south Australian coral species better when more explorative marine biodiversity research is done, especially along Indian Ocean coastlines.

Reef coral assemblages in uncommon marine environments, such as estuarine narrow bays that penetrate far inland, can be of particular interest with regard to the discovery of rare species, in this case Sarabua Bay. This estuarine environment is comparable to that of Bima Bay in NE Sumbawa, with an environmental gradient of decreasing oceanic influence in landward direction [22]. With the intensification of coral bleaching and growing anthropogenic pressure to coral reefs in the proximity of urban centres, such as Padang, marine biodiversity surveys in poorly investigated areas and habitats become increasingly necessary, especially if we want to understand which species are most susceptible to these threats.

As a taxonomic note, it is relevant to mention that two species, Coscinaraea marshae and C. moneilli, were reclassified by Rowlett [7] as representatives of a new genus, Australaraea, Rowlett, 2020. The main criteria for separating both species from Coscinaraea was their imperforate septa and restricted biogeographical range. The first character (imperforate septa) was just mentioned, but not demonstrated, and its validity as a diagnostic character was not supported by research. Rowlett [7] did not demonstrate that C. monile, as type species of Coscinaraea and as species most resembling C. marshae, does not have that character. Geographic range is also not a reliable character, as shown by the present result and the aforementioned examples of Astrangia woodsi, Echinomorpha nishihirai, and Leptoseris troglodyta [1-3]. The new genus Australaraea was not assigned to a family, because this would require further examination [7]. Since no evidence and explanation was provided regarding the imperforate septa, and because the biogeographical argument appears to be disproven by the present study, we consider Australaraea Rowlett, 2020, a junior synonym of Coscinaraea Milne Edwards and Haime, 1848. 
Author Contributions: Conceptualization, B.W.H.; data curation, B.W.H.; funding acquisition, A.K.; investigation, B.W.H., O.J. and A.K.; project administration, B.W.H. and A.K.; resources, B.W.H. and A.K.; validation, B.W.H.; visualization, B.W.H. and A.K.; writing-original draft preparation, B.W.H.; writing-review and editing, B.W.H., O.J. and A.K. All authors have read and agreed to the published version of the manuscript.

Funding: German Academic Exchange Service (DAAD-LZD-IDN0001-03/93) and the Leibniz Centre for Tropical Marine Research Bremen (ZMT).

Institutional Review Board Statement: Not applicable.

Informed Consent Statement: Not applicable.

Data Availability Statement: Data sharing not applicable.

Acknowledgments: The authors thank the coral reef team (Pusat Studi and Minang Bahari Divers) of Bung Hatta University, Padang, and the crew of KM Faperi for logistic support. Research permits were issued by Lembaga Ilmu Pengetahuan Indonesia (LIPI), Jakarta. The maps (Figure 3) were drawn by Erik-Jan Bosch (Naturalis). The authors are grateful to three reviewers for their comments on the manuscript.

Conflicts of Interest: The authors declare no conflict of interest.

\section{References}

1. Hoogenboom, M.O.; Frank, G.E.; Blowes, S.A.; Chase, T.J.; Zawada, K.J.A.; Dornelas, M. Disparity between projected geographic ranges of rare species: A case study of Echinomorpha nishihirai (Scleractinia). Mar. Biodivers. Rec. 2015, 8, e147. [CrossRef]

2. Viswambharan, D.; Sreenath, K.; Jasmine, S.; Joshi, K.K.; Sheeraj, C.R.; Mohan, S.; Rohit, P. Occurrence of the supposedly endemic Australian azooxanthellate coral Astrangia woodsi Wells, 1955 in the eastern Arabian Sea. Mar. Biodivers. 2021, 51, 84. [CrossRef]

3. Pichon, M.; Rouzé, H.; Barathieu, G.; Konieczny, O.; Adjeroud, M.; Thomassin, B. Extension of the known distribution of the scleractinian coral Leptoseris troglodyta to the southwestern Indian Ocean: New record from mesophotic submarine caves in Mayotte. Bull. Mar. Sci. 2020, 96, 783-784. [CrossRef]

4. Tenison-Woods, J.E. On the extratropical corals of Australia. Proc. Linn. Soc. N.S.W. 1878, 2, 292-341, pls. 4-6.

5. Veron, J.E.N. Corals in Space and Time. The Biogeography \& Evolution of the Scleractinia; Cornell University Press: Ithaca, NY, USA, $1995 ;$ p. 321.

6. Cairns, S.D.; Parker, S.A. Review of the recent Scleractinia (stony corals) of South Australia, Victoria and Tasmania. Rec. S. Austr. Mus. Monogr. Ser. 1992, 3, 1-82.

7. Rowlett, J. Indo-Pacific Corals; Joe Rowlett, Self-Published. 2020, p. 809.

8. Wells, J.W. Two new scleractinian corals from Australia. Rec. Austr. Mus. 1962, 25, 239-242. [CrossRef]

9. Veron, J.E.N. Corals of the World. Volume 2; Australian Institute of Marine Science: Townsville, Australia, 2000 ; p. 429.

10. Veron, J.E.N.; Marsh, L.M. Hermatypic corals of Western Australia: Records and annotated species list. Rec. West. Austr. Mus. Suppl. 1988, 29, 1-136.

11. Richards, Z.; Kirkendale, L.; Moore, G.; Hosie, A.; Huisman, J.; Bryce, M.; Marsh, L.; Bryce, C.; Hara, A.; Wilson, N.; et al. Marine biodiversity in temperate Western Australia: Multi-taxon surveys of Minden and Roe Reefs. Diversity 2016, 8, 7. [CrossRef]

12. Thomson, D.P.; Bearham, D.; Graham, F.; Eagle, J.V. High latitude, deeper water coral bleaching at Rottnest Island, Western Australia. Coral Reefs 2011, 30, 1107. [CrossRef]

13. Bessell-Browne, P.; Stat, M.; Thomson, D. Coscinaraea marshae corals that have survived prolonged bleaching exhibit signs of increased heterotrophic feeding. Coral Reefs 2014, 33, 795-804. [CrossRef]

14. Tuckett, C.A.; de Bettignies, T.; Fromont, J.; Wernberg, T. Expansion of corals on temperate reefs: Direct and indirect effects of marine heatwaves. Coral Reefs 2017, 36, 947-956. [CrossRef]

15. Longhurst, A.R.; Pauly, D. Ecology of Tropical Oceans; Academic Press: San Diego, CA, USA, 1987; p. 407.

16. Kunzmann, A. The coral reefs of West Sumatra. In The Ecology of the Indonesian Seas, Part II; Tomasick, T., Mah, A.J., Nontji, A., Moosa, M.K., Eds.; Periplus: Singapore, 1979; pp. 1249-1262.

17. Kunzmann, A. On the way to management of West Sumatra's coastal ecosystems. Naga ICLARM Quat. 2002, 25, 4-10.

18. Abram, N.J.; Gagan, M.K.; McCulloch, M.T.; Chappell, J.; Hantoro, W.S. Coral reef death during the 1997 Indian Ocean dipole linked to Indonesian wildfires. Science 2003, 301, 952-955. [CrossRef] [PubMed]

19. Hoeksema, B.W.; Cleary, D.F.R. The sudden death of a coral reef. Science 2004, 303, 1293. [CrossRef] [PubMed]

20. Mizerek, T.L.; Madin, J.S.; Benzoin, F.; Huang, D.; Luiz, O.J.; Mera, H.; Schmidt-Roach, S.; Smith, S.D.A.; Sommer, B.; Baird, A.H. No evidence for tropicalization of coral assemblages in a subtropical climate change hot spot. Coral Reefs 2021, 40, $1451-1461$. [CrossRef] 
21. Ross, C.L.; French, B.; Lester, E.K.; Wilson, S.K.; Day, P.B.; Taylor, M.D.; Barrett, N. Coral communities on marginal high-latitude reefs in West Australian marine parks. Diversity 2021, 13, 554. [CrossRef]

22. Hoeksema, B.W.; Moka, W. Species assemblages and ecomorph variation of mushroom corals (Scleractinia: Fungiidae) related to reef habitats in the Flores Sea. Neth. J. Sea Res. 1989, 23, 149-160. [CrossRef] 